\title{
Root morphological traits of oil palm genotypes with differential resistance to fatal yellowing
}

\section{Características morfológicas radiculares de genótipos de palma de óleo com resistência diferencial ao Amarelecimento Fatal}

\author{
Gerson Carlos Pinto Gloria ${ }^{1 *}$; Steel Silva Vasconcelos²; Rui Alberto Gomes \\ Junior $^{2}$; Alessandra de Jesus Boari2; Marcelo Murad Magalhães ${ }^{2}$
}

\section{Highlights}

We compared roots of oil palm genotypes with different tolerance to FY.

The biomass of fine and very fine root is higher in the hybrid than in its parents.

Fine and very fine root length is greater in the hybrid than in its parents.

The superiority of the hybrid's root system is due to overdominance.

\section{Abstract}

Brazil has an extensive area where the climate and soil are suitable for oil palm growing. However, in part of this area, production has been limited by the occurrence of the fatal yellowing (FY) anomaly, whose initial symptom is the rotting of absorptive roots. This symptom can be more severe in oil palm genetic materials with a smaller root system. The aim of this study was to examine morphological traits of roots and shoots of seedlings of three oil palm genotypes with different degrees of resistance to FY, namely, Tenera (sensitive), Caiaué (resistant) and Interspecific Hybrid (resistant) to provide bases to elucidate the differential resistance of these materials to FY. Shoot biomass did not vary statistically between the genetic materials. The mass, length and area of fine and very fine roots were significantly higher in the Interspecific Hybrid than in Caiaué and Tenera. The fine and very fine roots of Interspecific Hybrid had a larger mass than Caiaué (114 and 133\%, respectively) and Tenera (216 and 178\%, respectively). The Interspecific Hybrid also exhibited higher values for the length of fine and very fine roots than Caiaué (155 and 99\% respectively) and Tenera (228 and 94\% respectively). The root traits of the Interspecific Hybrid and Tenera are compatible with their differential resistance to FY. Our results demonstrate the importance of expanding the study of the relationship between root morphology and resistance to FY in these genetic materials under conditions that favor the occurrence of the anomaly, such as flooding.

Key words: Leaf area. Fatal Yellowing. Heterosis. Oil palm. Specific root length.

${ }^{1}$ Graduate Student, Universidade Federal Rural da Amazônia, Institute of Agrarian Sciences, Belém, PA, Brazil. E-mail: gersoncarllos@hotmail.com

2 Researcher, Empresa Brasileira de Pesquisa Agropecuária, EMBRAPA Amazônia Oriental, Belém, PA, Brazil. E-mail: steel.vasconcelos@embrapa.br; rui.gomes@embrapa.br; alessandra.boari@embrapa.br; marcelo.magalhaes@ embrapa.br

* Author for correspondence

Received: July 15, 2020 - Approved: July 14, 2021 


\section{Resumo}

O Brasil possui uma extensa área com clima e solo aptos ao plantio de palma de óleo. No entanto, a produção em parte desta área tem sido limitada pela ocorrência da anomalia Amarelecimento Fatal (AF), cujo sintoma inicial é o apodrecimento das raízes de absorção. Esse sintoma pode ser mais severo em materiais genéticos de palma de óleo que apresentem sistema radicular reduzido. O objetivo foi avaliar características morfológicas de raízes e parte aérea de mudas de três genótipos de palma de óleo com graus diferentes de resistência ao AF: Tenera (sensível), Caiaué (resistente) e Híbrido Interespecífico (resistente) para fornecer subsídios ao entendimento da resistência diferencial desses materiais ao AF. A biomassa da parte aérea não variou estatisticamente entre os materiais genéticos. Massa, comprimento e área de raízes finas e muito finas foram significativamente maiores no Híbrido Interespecífico do que no Caiaué e no Tenera. O Híbrido Interespecífico apresentou valores de massa de raízes finas e muito finas superiores em relação ao Caiaué (114 e 133\%, respectivamente) e Tenera (216 e 178\%, respectivamente). O Híbrido Interespecífico também apresentou valores superiores de comprimento de raízes finas e muito finas em relação ao Caiaué (155 e 99\% respectivamente) e Tenera (228 e 94\% respectivamente). As características radiculares do Híbrido Interespecífico e do Tenera são compatíveis com sua resistência diferencial ao AF. Nossos resultados demonstram a importância de ampliar o estudo da relação entre morfologia radicular e resistência ao AF destes materiais genéticos em condições que favoreçam a ocorrência da anomalia, como alagamento.

Palavras-chave: Amarelecimento Fatal. Área foliar. Comprimento específico de raiz. Dendê. Heterose.

\section{Introduction}

Palm oil is widely used worldwide, mainly for food $(71 \%)$ and in the production of cosmetics (24\%) and energy (5\%) (United States Department of Agriculture [USDA], 2019). Brazil is the 9th largest producer of palm fruit (Food and Agriculture Organization [FAO], 2021) and oil (USDA, 2021) in the world. The annual Brazilian production of around 360,000 $t$ of palm oil and $30,000 \mathrm{t}$ of palm kernel oil is insufficient to meet the domestic demand of $506,071 \mathrm{t}$ of palm oil and $233,000 \mathrm{t}$ of palm kernel oil (Ministério da Agricultura Pecuária e Abastecimento [MAPA], 2018). Therefore there is a great need to expand oil palm cultivation to minimize the heavy dependence on imports.

The Amazon has soil and climate conditions favorable to the cultivation of oil palm and concentrates $91 \%$ of the total area planted with this crop in Brazil. However, insome places of the Brazilian Amazon, the expansion of the crop has been limited by the occurrence of an anomaly known as fatal yellowing (FY). As the name suggests, FY causes yellowing of the basal leaflets of intermediate leaves and, over time, it can result in the plant's total drying out and, ultimately, its death (Duff, 1963; Turner \& Planters, 1981; Trindade, Poltronieri, \& Furlan, 2005).

In the soil, FY causes root rot, which is indeed the primary symptom of FY (Van Slobbe, 1991), as it appears before foliar symptoms. Fatal yellowing reduces the growth of tertiary and quaternary roots (Albertazzi, Bulgarelli, \& Chinchilla, 2005). Accordingly, plants affected by $\mathrm{FY}$ have a reduced root system when compared with plants without FY symptoms (Ayala, 2001). 
The etiology of FY is still unknown, but its occurrence is related to certain environmental conditions. There is a direct relationship between high rainfall and the development of a favorable environment (e.g. less soil aeration) for the appearance of FY (Turner \& Planters, 1981; Monge, Chinchilla, \& Wang, 1993; Alvarado, Chinchilla, Bulgarelli, \& Sterling, 1997; Chinchilla \& Durán, 1998, 1999; De Franqueville, 2001; Venturieri, Fernandes, Boari, \& Vasconcelos, 2009). Floods or water table elevation affect the development of the root system in oil palm, significantly reducing its root density (Albertazzi, Chinchilla , \& Ramírez, 2009). In some cases, however, these negative effects on the roots do not manifest in the shoot (Da Ponte et al., 2019; Kastelein, Van Slobbe, \& De Leeuw, 1990).

According to the principle of functional balance (Le Chatelier, 2010), a stable system under stress undergoes morphological changes in an attempt to minimize stress. These changes are responses of biomass allocation to different plant organs, and may be governed by genetic factors (Poorter \& Nagel, 2000). Biomass changes are usually accompanied by alterations in other secondary variables (architecture, density, volume), which are directly or indirectly affected by stress (Szaniawski, 1983). Therefore, resistance to FY may be related to a greater or lesser ability of the plant to minimize the negative effects of water balance through uptake organs, mainly by stimulation of root system development and translocation of assimilates (Da Ponte et al., 2019).

The Interspecific Hybrid (ISH) of oil palm (Elaeis oleifera $\times$ Elaeis guineensis), a genetic material resistant to $F Y$, has been planted in areas vulnerable to the occurrence of this anomaly (Homma, 2016). There is a morphological difference in the shoots between ISH and the African oil palm (E. guineensis) (Corley \& Tinker, 2016). The root system of these genetic materials is possibly also different. Therefore, our objective was to evaluate morphological traits of the root system and shoots of these genotypes to provide bases to elucidate the differential resistance of these materials to $\mathrm{FY}$.

\section{Material and Methods}

We developed this study in 2017 at the Laboratory of Sustainable Systems Analysis (LASS) at Embrapa Eastern Amazon, in BelémPA, Brazil (48 $26^{\prime} 45^{\prime \prime} \mathrm{W}$ and $\left.1^{\circ} 26^{\prime} 31^{\prime \prime} \mathrm{S}\right)$. We evaluated eight-month-old seedlings of ISH, Tenera (E. guineensis $\times$ E. guineensis) and Caiaué (E. oleifera) grown in a greenhouse. We planted pre-germinated seeds originating from the germplasm bank of Embrapa Western Amazon (10/24/2016) in black polyethylene bags $(15 \times 28 \mathrm{~cm})$ filled with soil substrate and chicken manure. The seedlings grew under the same light and management conditions in the greenhouse.

\section{Shoot biomass}

To measure the shoot biomass, we identified the leaves of each seedling, starting with the spear leaf (leaf 1, in this study), and numbered the remaining leaves following the spiral arrangement until the last green leaf. We detached all the leaves by making a basal cut on the petiole, leaving only the bulb at the end, which we cut close to the insertion of the roots.

Next, we separated the petiole from the leaf blade. We captured images (300 dpi) of each leaf blade with an Epson desktop scanner, model J371A, and converted them 
into binary images using Image $J^{\circledR}$ V.1.46 software, National Institute of Health, USA. We used a millimeter scale on each generated image for software calibration (Figure 1). We performed this procedure on 10 different images with the same DPI value and used the average ( 118.20 pixels/cm) as the default resolution throughout the assessment of leaf area. Then, we dried the leaf blade, petiole and bulb in a forced-air oven $\left(65^{\circ} \mathrm{C}, 72 \mathrm{~h}\right)$ and weighed them on a precision scale with three decimal places. Finally, we added the total leaf dry mass (blade + petiole) and bulb dry mass to determine the total shoot biomass.

\section{Root biomass}

To evaluate root biomass, we washed the root system of each plant (Figure 2) with running water over a set of sieves in a decreasing mesh sequence ( 2 and $0.30 \mathrm{~mm}$ ). Then, we separated the roots according to the following diameter classes: coarse $1>1$ $\mathrm{mm})$, fine (0.50-0.99 $\mathrm{mm})$ and very fine (0.25$0.49 \mathrm{~mm}$ ). From each sample, we scanned a subsample of approximately 10, 1.0 and 0.5 $\mathrm{g}$ of each root class (coarse, fine and very fine, respectively). Subsequently, we dried the sample and subsamples of all roots in a forcedair oven $\left(65^{\circ} \mathrm{C}, 72 \mathrm{~h}\right)$. Afterwards, we calculated the total root system biomass as the sum of the biomass of the root classes (dry mass of samples + respective root subsamples of each diameter class) of each plant (Gloria, 2016).

To determine root length, we used the SmartRoot plugin of ImageJ ${ }^{\circledR}$ software (Costa, Cunha, Jorge, \& Araújo, 2014; Delory et al., 2017). Preliminary tests revealed that the resolution was $35,367,39,300$ and 39,335 pixels/cm for the coarse, fine, and very fine roots, respectively

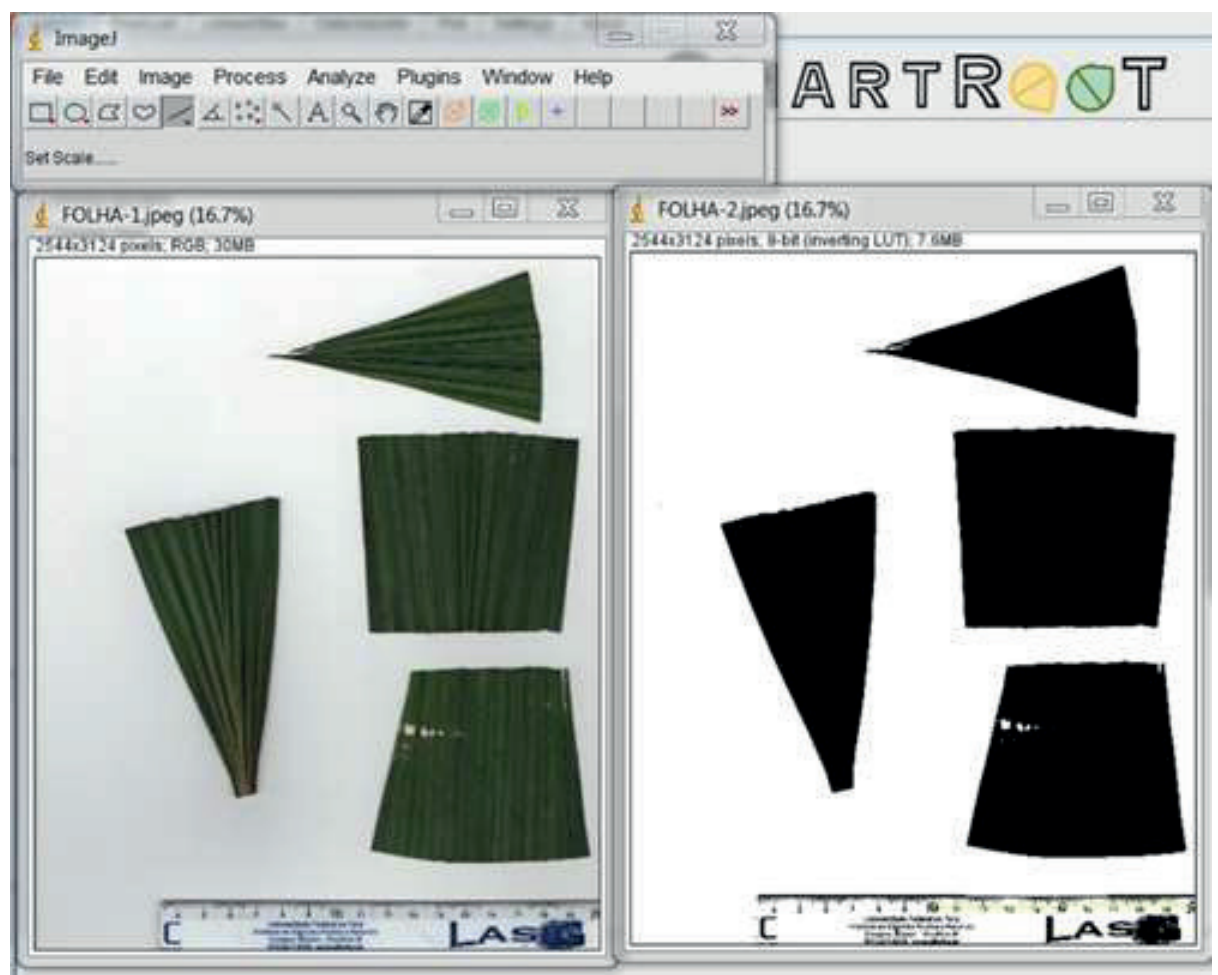

Figure 1. Scanned images of pieces of leaf blades from oil palm seedlings. 


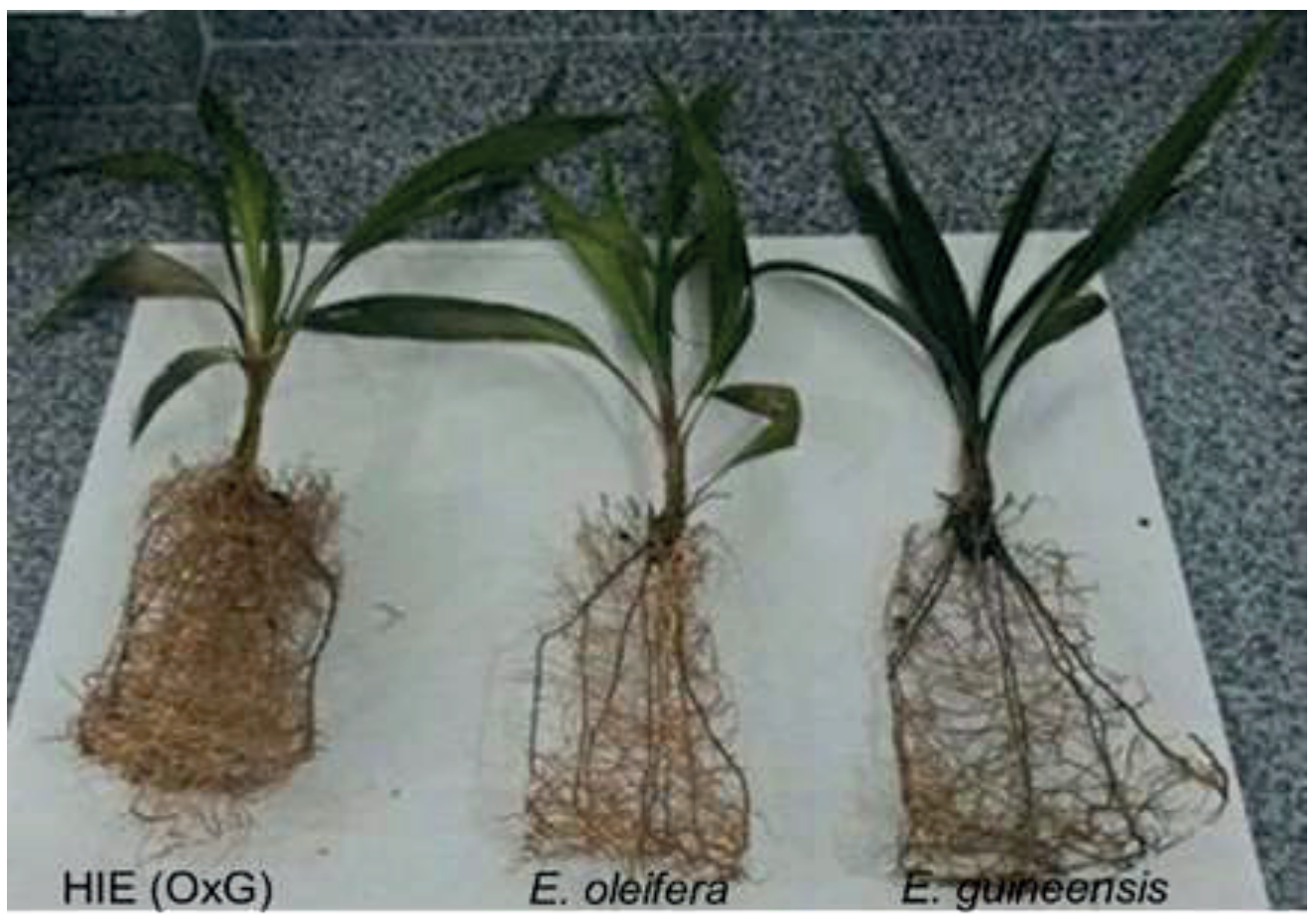

Figure 2. Root system of Interspecific Hybrid (HIE), Caiaué (Elaeis oleifera) and Tenera (Elaeis guineensis) seedlings.

Still in the phase of methodology adjustments, we chose to use the Trace Root tool instead of the Automatic Drawing mode, as the former was more precise and specific. In addition, fine and very fine root fragments were not detected in Automatic Drawing mode. To estimate the total length, we applied the following equation: $L t=\frac{L_{s s} \times M_{t}}{M_{s s}}$, where $L t$ is the total length; $L_{s s^{\prime}}$ the subsample length; $M_{t^{\prime}}$ the total dry mass (sample + subsample); and $\mathrm{M}_{\mathrm{ss}}$ the subsample dry mass. We estimated root area with the following equation: $A=2 \times \pi$ $\times r \times L$, where $r$ is the radius of the roots (in $\mathrm{cm}$ ) and $L$ is the length of the subsample (in $\mathrm{cm}$ ). To estimate the root area, we considered $r$ as the intermediate value of the variation range of each diameter class, that is, $0.125 \mathrm{~cm}$ for coarse roots, $0.075 \mathrm{~cm}$ for fine roots and $0.037 \mathrm{~cm}$ for very fine roots.

We calculated specific root length as the ratio between total length and total dry mass. We calculated the root/shoot ratio for both biomass and area using the following equations: $=\frac{\text { Root biomass }}{\text { Shoot biomass }}$ and Area ratio $=\frac{\text { Root area }}{\text { Leaf area }}$, respectively.

The experiment was laid out in a completely randomized design with 20 replicates $(n=20)$ and one plant per plot. We applied a one ANOVA to test the effect of genetic material on shoot and root variables using SigmaPlot software version 14.0. We performed Tukey's test at $5 \%$ for mean comparison. Table 1 shows the coefficient of variation of the analyzed variables. 
Table 1

Coefficient of variation of dependent variables

\begin{tabular}{|ccccc|}
\hline Variable & \multicolumn{4}{c}{ Coefficient of variation (\%) } \\
\cline { 2 - 5 } Shoot biomass & Total & Coarse & Fine & Very fine \\
\hline Leaf area & 15.83 & - & - & - \\
\hline Root biomass & 14.13 & - & - & - \\
\hline Root length & 49.59 & 34.16 & 73.52 & 91.75 \\
Root area & - & 71.68 & 82.95 & 67.45 \\
\hline Specific root length & - & 71.68 & 82.95 & 67.45 \\
\hline Root mass/Leaf mass ratio & - & 39.51 & 25.04 & 34.20 \\
\hline Root area/Leaf area ratio & 45.98 & - & - & - \\
\hline
\end{tabular}

\section{Results and Discussion}

Shoot biomass did not differ between the evaluated materials (ISH: $9.92 \pm 0.66 \mathrm{~g}$ plant ${ }^{-1}$, Caiaué: $9.45 \pm 0.69$ g plant $^{-1}$ and Tenera: $8.25 \pm 0.99$ g plant $^{-1}$ ) (Figure 3A). The leaf area of ISH (10.12 $\pm 0.51 \mathrm{~m}^{2}$ plant $\left.{ }^{-1}\right)$ was significantly larger than that of Caiaué $\left(7.97 \pm 0.25 \mathrm{~m}^{2}\right.$ plant $\left.^{-1}\right)$, where as the leaf area of Tenera (8.57 $\pm 0.73 \mathrm{~m}^{2}$ plant $^{-1}$ ) did not differ significantly from those of other genetic materials (Figure 3B). In the literature, differences are described both for shoot biomass accumulation and leaf area between ISH and Tenera. In Colombia, the shoot biomass and leaf area of 11-monthold seedlings of ISH were higher than those of Tenera (Ibarra-Ruales \& Reyes-Cuesta, 2015). Similarly, the leaf area of ISH was larger than that of its parents (E. oleifera and E. guineensis), in studies with adult plants (Hardon, Williams, \& Watson, 1969; Hartley, 1988).

The total root dry mass of ISH was higher than that of the other materials $(71.7 \%$ higher compared with Caiaué; and 109.8\% higher compared with Tenera) (Figure 4). These results suggest that $\mathrm{ISH}$ allocates more biomass to the root system, since the genetic materials did not differ statistically for shoot mass. The Interspecific Hybrid also had higher mass values of the main absorptive roots the fine (Figure $5 B$ ) and very fine (Figure $5 \mathrm{C})$ roots as compared with the other genetic materials, agreeing with a possible genetic factor (overdominance). The difference in root area and length between ISH and the other genetic materials is also consistent with the overdominance hypothesis. The overdominance hypothesis proposed by Shull (1908) postulates that the cause of heterosis are the heterozygous genes, which are always superior to homozygous genes for the same locus. Thus, F1 individuals, such as the Hybrid, may express overdominance relative to their parents, as observed for other crops (Souza, Magalhães, Castro, Duarte, \& Lavinsky, 2016). 


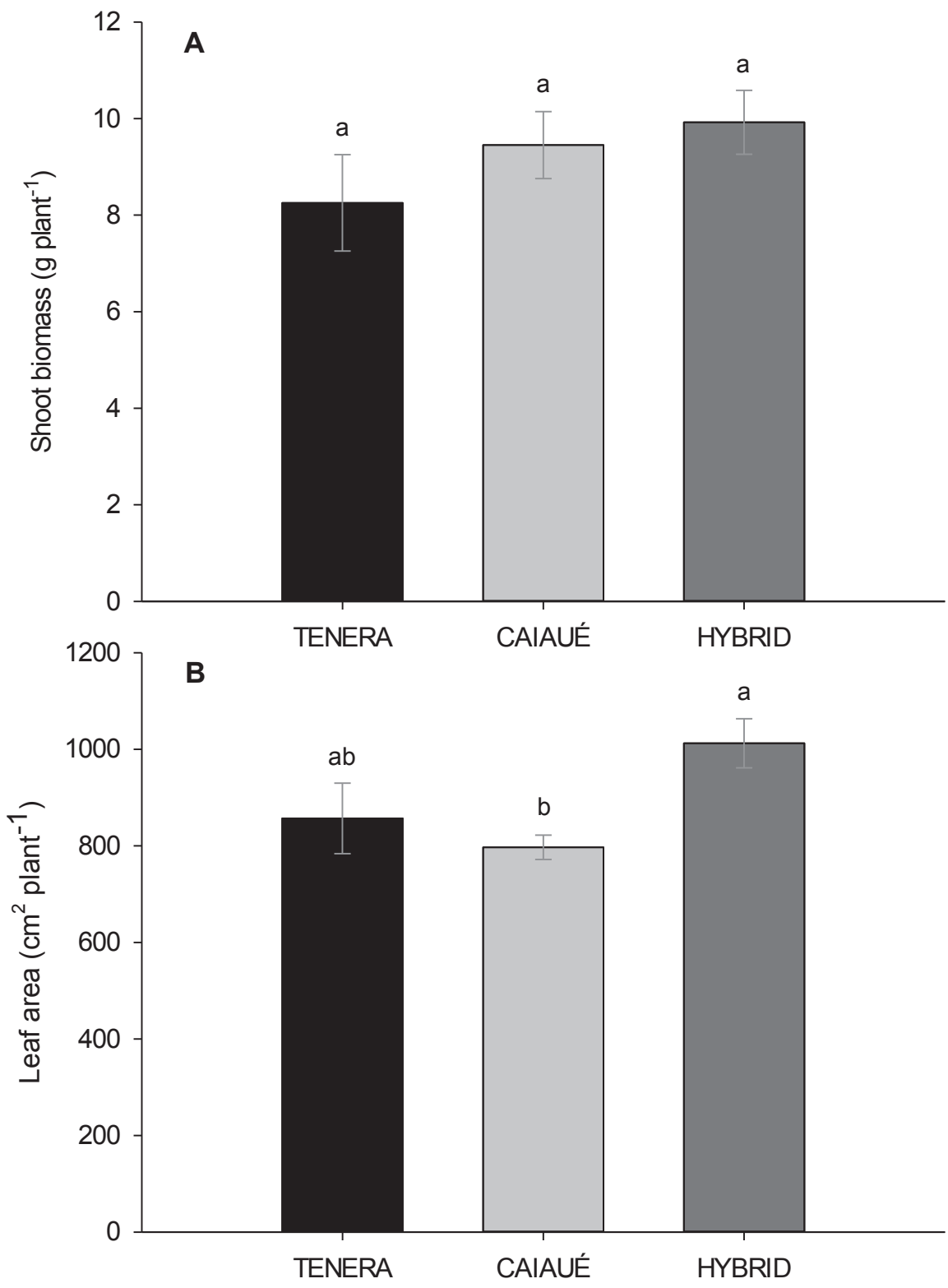

Figure 3. Shoot biomass (A) and leaf area (B) of eight-month-old seedlings of oil palm genotypes Tenera, Caiaué and Interspecific Hybrid. Data are expressed as mean \pm standard error $(n=20)$. Different letters indicate a significant difference between means by Tukey's test $(p<0.05)$.

The overdominance hypothesis may explain the results of the root system of the Hybrid, which showed a larger dry mass of fine (Figure $5 \mathrm{~B}$ ) and very fine (Figure $5 \mathrm{C}$ ) roots than the other genetic materials. This finding suggests that the Interspecific Hybrid has a greater nutrient scavenging and absorption potential than Tenera and Caiaué. On the other hand, there was no difference in the biomass of coarse roots (Figure 5A), which are more closely related to maintenance structures (support, reserves) (Corley \& Tinker, 2016). 


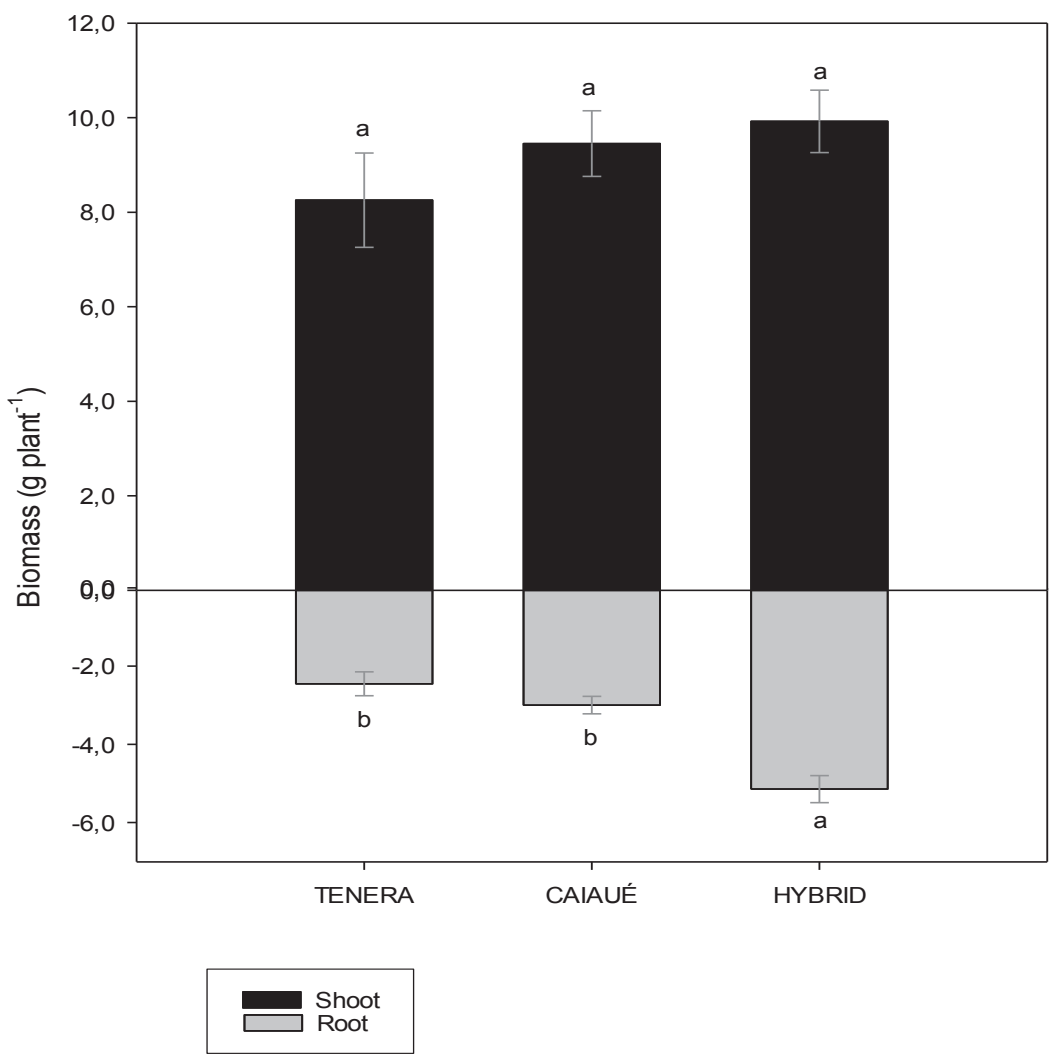

Figure 4. Shoot biomass and root biomass of eight-month-old seedlings of oil palm genotypes Tenera, Caiaué and Interspecific Hybrid. Data are expressed as mean \pm standard error $(n=20)$. Different letters indicate a significant difference between means by Tukey's test $(p<0.05)$.

The greater length of absorptive roots in the Interspecific Hybrid (Figures $5 \mathrm{E}-\mathrm{F}$ ) in our study is not expressed solely under favorable growth conditions (without nutrient, water and light restrictions). In another study, a prolonged water deficit (57 days) caused a $12 \%$ increase in total root length and a $41.7 \%$ reduction in the root biomass of seedlings of hybrids (BRS Manicoré and BRS C 2501) at one year of age (Silva et al., 2017). Thus, the study of Silva et al. (2017) shows that the Interspecific Hybrid allocates energy to increase the absorption potential in situations of reduced water availability.

Specific root length allows evaluating how a plant invests its photoassimilates between supporting (coarse roots) and resource capture (fine roots) structures (Eissenstat \& Yanai, 1997). In this study, Tenera showed the highest specific root length value. The high specific root length values of the fine (Figure 5L) and very fine (Figure 5M) root classes of Tenera suggest that this genetic material allocates many of its photosynthates to increase branching rather than diameter. Such increased root branching strategy is a trait that exists not only in palm, but also in other plant species with high specific root length values (Bilbrough \& Caldwell, 1995; Bouma, Nielsen, Van Hal, \& Koutstaal, 2001; Pregitzer, Kubiske, Yu, \& Hendrick, 1997). 

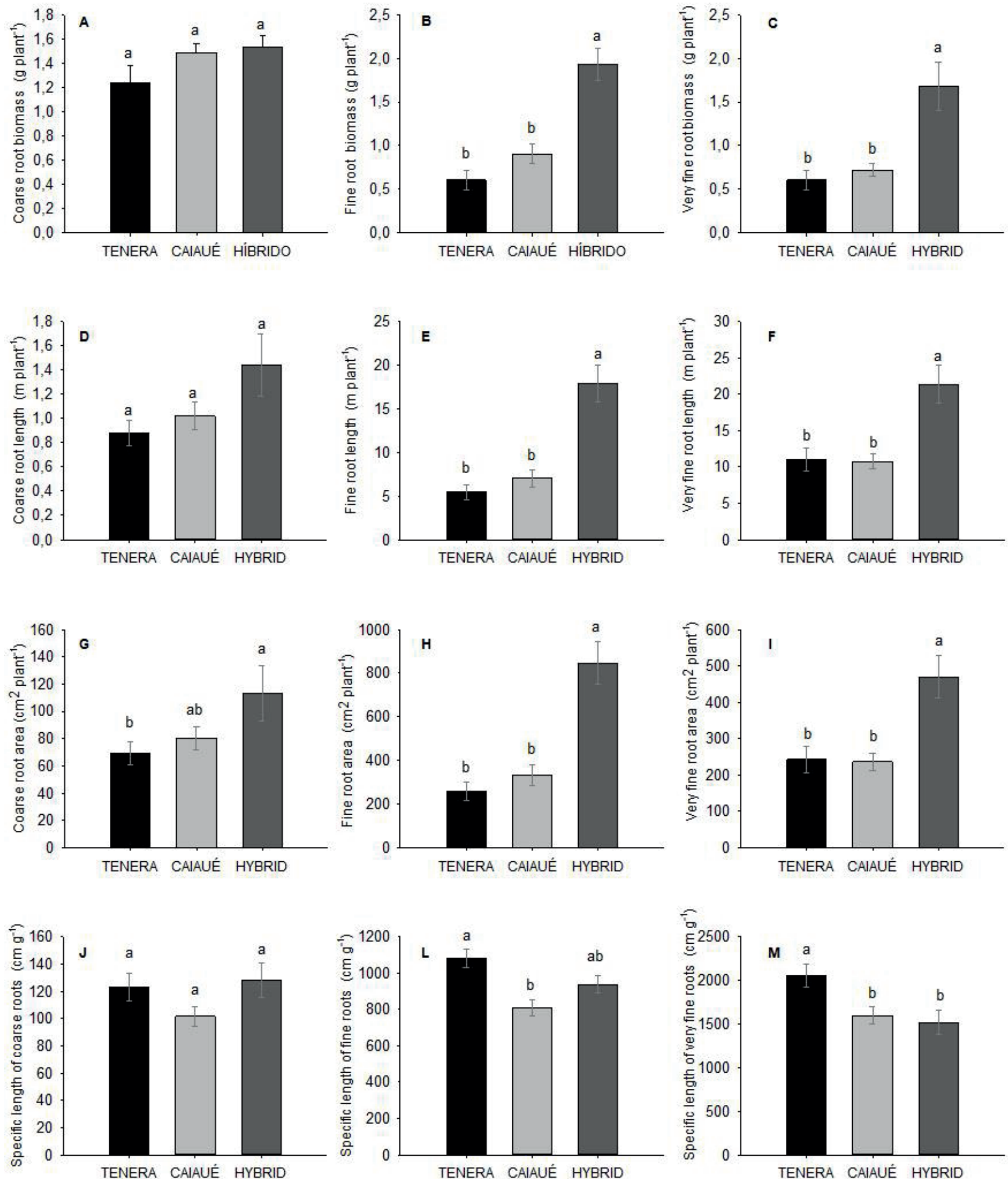

Figure 5. Root system variables of eight-month-old seedlings of oil palm genotypes Tenera, Caiaué and Interspecific Hybrid. Data are expressed as mean \pm standard error $(n=20)$. Different letters indicate a significant difference between genetic materials by Tukey's test $(p<0.05)$. 
Although Tenera exhibited the greatest specific root length, its dry mass and root length were lower than those of ISH and equal to those of Caiaué, which suggests that Tenera roots have a smaller diameter or less tissue density than those of the other two genetic materials. Roots with low tissue density have shorter longevity, a trait that may be unfavorable to Tenera, since FY early effects occur in the root system (Van Slobbe, 1991; Bernardes, 2001), affecting the meristematic region of the roots (Kastelein et al., 1990).

In oil palm, there is a positive relationship between the root system and resistance to FY. However, it is not possible to state that root biomass alone is responsible for the resistance of Caiaué and HIE to FY, since Caiaué showed similar root length and dry mass values to those of Tenera, a material susceptible to FY, in our study. Thus, it is possible that the greater resistance of Caiaué over Tenera is associated with a greater amount of tanniferous cells present in the roots of Caiaué (Barcelos, 1986). In addition, Tenera is more susceptible to environmental stress in its shoots, as compared with Caiaué and HIE (Chia, 2012). The proportion in which plants invest their photoassimilates for root system development whether this is influenced by endogenous or exogenous factors can be measured by the root/leaf mass and root/leaf area ratios. The higher the ratio, the greater the energy input for root development relative to shoot development (Marschner, 1986; Rodríguez \& Leihner, 2006). Therefore, both the root biomass and root/shoot mass ratio results (Figure 6A) indicate that ISH allocates more energy for the development of its root system as compared with the other genetic materials. This pattern can also be seen in the root/leaf area ratio (Figure 6B), which suggests that ISH has a greater below-ground resourcecapturing potential than the other genetic materials.

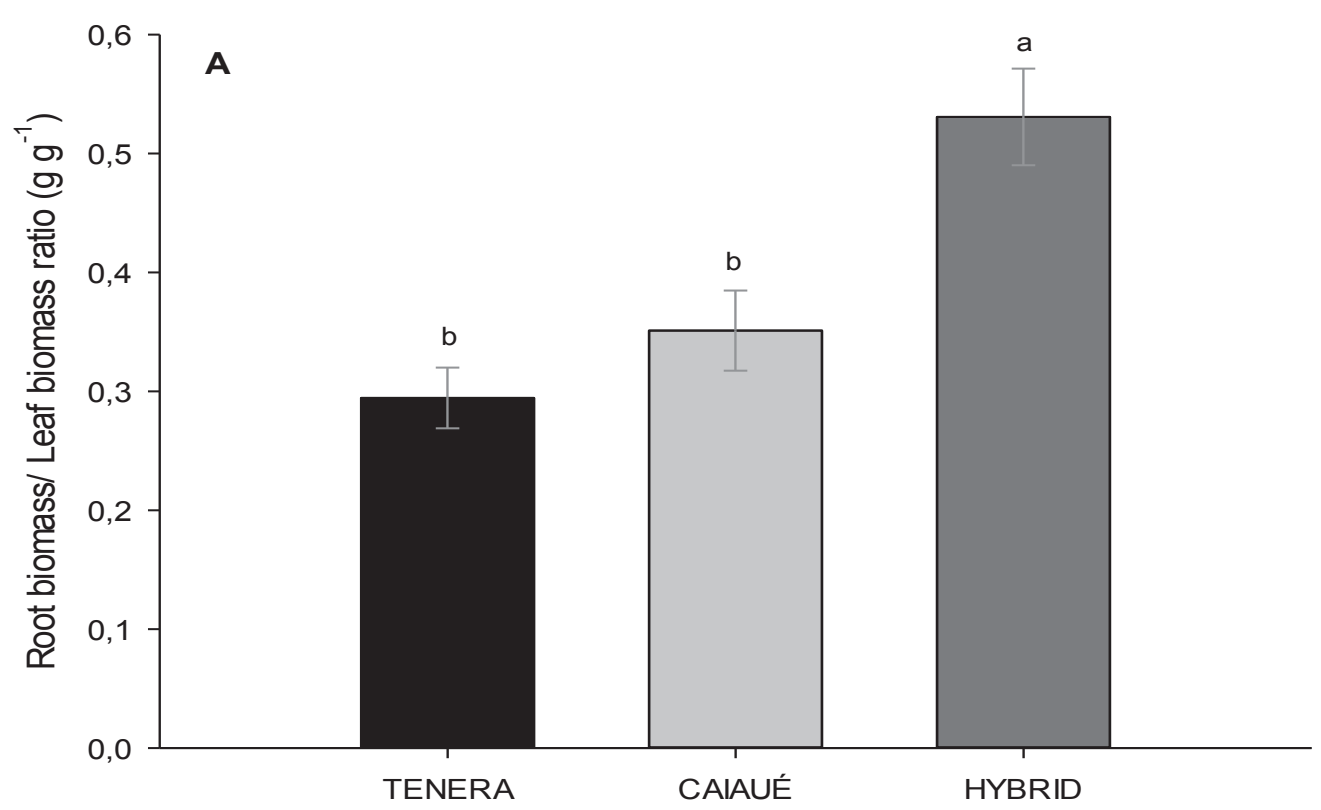

continue... 
contuation...

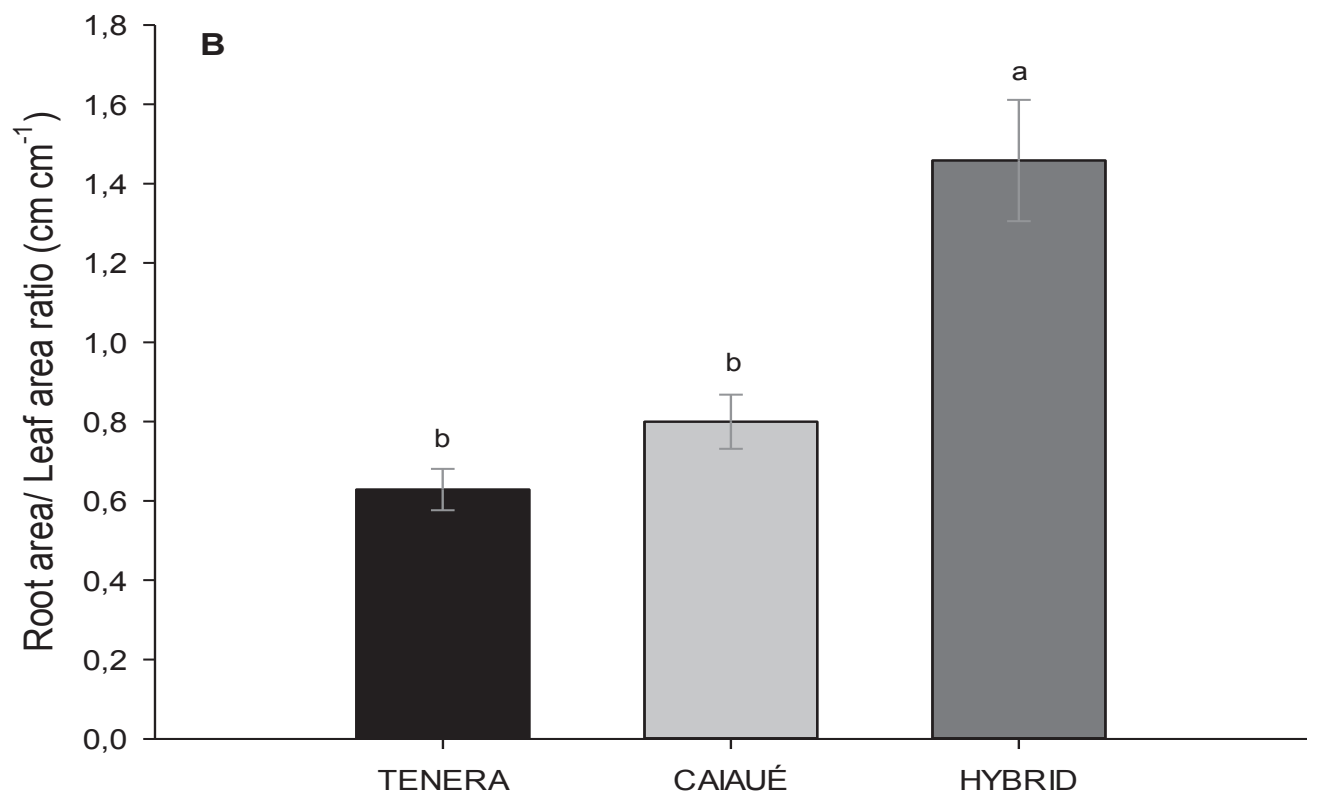

Figure 6. Ratios between root mass and shoot mass $(A)$ and between root area and leaf area (B) of seedlings of oil palm genotypes Tenera, Caiaué and Interspecific Hybrid. Data are expressed as mean \pm standard error $(n=20)$. Different letters indicate a significant difference between genetic materials by Tukey's test $(p<0.05)$.

The morphological differences exhibited by ISH relative to the other genetic materials can be advantageous under other limiting conditions, such as deficient soil nutrients. Its greater biomass allocation to the root system, as compared with that of its parents, allows better exploration of water and nutrients in the soil, which is potentially useful in regions with environmental limitations.

In fact, in environments with some type of resource limitation, the growth of Tenera can be strongly affected. In Côte d'Ivoire (Dufrêne, 1989; Dufrêne, Ochs, \& Saugier, 1990; Dufrêne, Bernard, Rey, Quencez, \& Saugier, 1992), water deficit resulted in high root biomass and restricted shoot growth in oil palm (Tenera), leading to a root/shoot ratio higher than $0.9 \mathrm{~g}$ $\mathrm{g}^{-1}$, which is considerably higher than the value observed in our study $\left(0.3 \mathrm{~g} \mathrm{~g}^{-1}\right)$. On the other hand, excess water (flooding) can compromise root development, but not the shoot biomass of Tenera (Da Ponte et al., 2019), causing high root/shoot mass values $\left(0.25 \mathrm{~g} \mathrm{~g} \mathrm{~g}^{-1}\right)$, similar to the results found in our study $\left(0.3 \mathrm{~g} \mathrm{~g}^{-1}\right)$ and reported by Henson and Chai (1997) in three-year-old plants. Thus, the sensitivity of Tenera to abiotic factors, coupled with the low allocation of biomass to the root system, may contribute to the susceptibility of this material to $F Y$, which is not true for ISH.

\section{Conclusions}

The mass, length and area of fine and very fine roots were significantly higher in the Interspecific Hybrid (ISH), a material resistant 
to FY, as compared with Tenera, a susceptible material. However, our study does not allow inferring whether there is a causal relationship between the root system and resistance to $\mathrm{FY}$, thus warranting further experimentation to investigate ISH in environments with FY. The intermediate values of root mass and length of the other resistant material (Caiaué) suggest that the morphology of the root system (biomass and length) alone may not be the factor responsible for resistance to FY.

\section{Authors' contributions}

Rui Gomes Junior and Alessandra de Jesus Boari cultivated the seedlings in the greenhouse. Gerson Carlos Pinto Gloria and Steel Silva Vasconcelos designed and conducted laboratory experiments. Gerson Carlos Pinto Gloria, Steel Silva Vasconcelos, Rui Gomes Junior, Alessandra de Jesus Boari and Marcelo Magalhães Murad composed the article.

\section{Acknowledgments}

The authors thank the Amazon Foundation for the Support of Studies and Research (FAPESPA) for the doctoral grant; and the team at the Laboratory of Sustainable Systems Analysis at Embrapa Eastern Amazon for their logistical and technical support.

\section{References}

Albertazzi, H., Bulgarelli, J., \& Chinchilla, C. (2005). Onset of spear rot symptoms in oil palm and prior (and contemporary) events. ASD Oil Palm Papers, 28, 21-33.
Albertazzi, H., Chinchilla, C., \& Ramírez, F. (2009). Soil characteristics and root development in young oil palms (Elaeis guineensis Jacq.) planted in sites affected by bud rots (pudrición del cogollo). ASD Oil Palm Papers, 33, 1-14.

Alvarado, A., Chinchilla, C. M., Bulgarelli, J., \& Sterling, F. (1997). Factores agronómicos asociados a la "pudrición común de la flecha / arqueo foliar" en palma aceitera. ASD Oil Palm Papers, 15, 8-28.

Ayala, L. S. (2001). Pesquisa sobre amarelecimento fatal do dendezeiro. Belém: DENPASA.

Barcelos, E. (1986). Características genético e ecológicas de populações naturais de caiaué (Elaeis oleifera (H.B.K) Cortés) na Amazônia Brasileira. Dissertação de mestrado, Instituto Nacional de Pesquisas da Amazônia, Manaus, AM, Brasil.

Bernardes, M. S. R. (2001). Relatório de visitas à plantação de Paricatuba, na Denpasa, visando à identificação das causas do AF. Belém: DENPASA.

Bilbrough, C. J., \& Caldwell, M. M. (1995). The effects of shading and $\mathrm{N}$ status on root proliferation in nutrient patches by the perennial grass Agropyron desertorum in the field. Oecologia, 103(1), 10-16. doi: 10.1007/BF00328419

Bouma, T. J., Nielsen, K. L., Van Hal, J., \& Koutstaal, B. (2001). Root system topology and diameter distribution of species from habitats differing in inundation frequency. Functional Ecology, 15(3), 360-369. doi: 10.1046/j.1365-2435.2001.00523.x

Chia, G. S. (2012). Caracterização morfofisiológica e anatômica de folhas de dendezeiro (Elaeis guineensis Jacq.), 
de caiaué (E. oleifera (Kunth) Cortés) e híbrido interespecífico (E. guineensis $x$ E. oleifera) nas condições da Amazônia. Tese de doutorado, Universidade Federal do Amazonas, Manaus, AM, Brasil. Recuperado de https://tede.ufam.edu.br/

Chinchilla, C. M., \& Durán, N. (1998). Manejo de problemas fitosanitarios en palma de aceite. Una perspectiva agronómica. Revista Palmas, 19, 242-256.

Chinchilla, C. M., \& Durán, N. (1999). Nature and management of spear rot-like problems in oil palm: a case study in Costa Rica. Annals of International Palm Oil Congress, Kuala Lumpur, MY, Malaysia.

Corley, R. H. V., \& Tinker, P. B. (2016). The oil palm (5nd ed). Oxford, UK: Wiley Blackwell.

Costa, M. C. G., Cunha, I. M. L., Jorge, L. A. C., \& Araújo, I. C. S. (2014). Public-domain software for root im-age analysis. Revista Brasileira de Ciência do Solo, 38(5), 1359-1366. doi: 10.1590/S0100-068320 14000500001

Da Ponte, N. H. T., Nunes Santos, R. I., Lima Lopes, W. R., Fo., Lisboa Cunha, R., Murad Magalhães, M., \& Alves Pinheiro, H. (2019). Morphological assessments evidence that higher number of pneumatophores improves tolerance to long-term waterlogging in oil palm (Elaeis guineensis) seedlings. Flora, 250, 52-58. doi: 10.1016/j.flora.2018.11.017

De Franqueville, H. (2001). La pudrición del cogollo de la palma aceitera en América Latina. Montpellier: Cirad, Departamento de Cultivos Perennes.

Delory, B. M., Weidlich, E. W. A., Meder, L., Lütje, A., Duijnen, R. V., Weidlich, R., \& Temperton,
V. M. (2017). Accuracy and bias of methods used for root length measurements in functional root research. Methods in Ecology and Evolution, 8(11), 1594-1606. doi: 10.1111/2041-210X.12771

Duff, A. (1963). The bud rot little leaf disease of the oil palm. Journal of West African Institute for Oil Palm Research, 4(14), 176-190.

Dufrêne, E. (1989). Photosynthese, consummation en eau et modelisation de la production chez le palmier a huile (Elaeis guineensis Jacq.). Thèse de Doctorat. Université de Paris-Sud, Orsay.

Dufrêne, E., Dubos, B., Rey, H., Quencez, P., \& Saugier, B. (1992). Changes in evapotranspiration from an oil palm stand (Elaeis guineensis Jacq.) exposed to seasonal soil water deficits. Acta Oecologica, 13(3), 299-314.

Dufrene, E., Ochs, R., \& Saugier, B. (1990). Oil palm photosynthesis and productivity linked to climatic factors. Oleagineux, 45(8-9), 345-355.

Eissenstat, D. M., \& Yanai, R. D. (1997). The ecology of root lifespan. In Advances in Ecological Research, 27, 1-60. doi: 10.1016/S0065-2504(08)60005-7

Food and Agriculture Organization (2021). Top 20 countries - production of oil palm fruit in 2019. Retrieved from http://www.fao. org/faostat/en/\#rankings/countries_by_ commodity

Gloria, G. C. P. (2016). Biomassa de raízes em plantio de híbrido interespecífico de Palma de óleo no leste da Amazônia. Tese de mestrado, Universidade Federal Rural da Amazônia, Belém, PA, Brasil. 
Hardon, J., Williams, C., \&Watson, I. (1969). Leaf area and yield in the oil palm in Malaya. Experimental Agriculture, 5(1), 25-32. doi: $10.1017 / S 0014479700009935$

Hartley, C. W. S. (1988). The oil palm (3rd ed). London: Longman.

Henson, I. E., \& Chai, S. H. (1997). Analysis of oil palm productivity. II. Biomass, distribution, productivity and turnover of the root system. Journal of Oil Palm Research, 9(2), 78-92.

Homma, A. K. O. (2016). Histórico do desenvolvimento de híbridos interespecíficos entre caiaué e dendezeiro. Belém: EMBRAPA Amazônia Oriental.

Ibarra-Ruales, L. N., \& Reyes-Cuesta, R. (2015). Crecimiento en vivero de las palmas aceiteras Elaeis oleiferaxElaeis guineensis y Elaeis guineensis $x$ Elaeis guineensis en Tumaco Colombia. Corpoica Ciencia \& Tecnologia Agropecuría, 16(2), 239-250. doi: 10.21930/rcta.vol16_num2_art:370

Kastelein, P., Van Slobbe, W. G., \& De Leeuw, G. T. N. (1990). Symptomatological and histopathological observations on oil palms from Brazil and Ecuador affected by fatal yellowing. Netherlands Journal of Plant Pathology, 96, 113-117. doi: 10. 1007/BF02005135

Le Chatelier, H. (2010). Recherches experimentales et theoretiques sur les equilibres chimques. Paris: Dunod, Kessinger Publishing.

Marschner, H. (1986). Mineral nutrition of higher plants. London: Academic Press.

Ministério da Agricultura Pecuária e Abastecimento (2018). Diagnóstico da produção sustentável da palma de óleo.
Recuperado de https://aprobio.com.br/ novosite/wp-content/uploads/2018/08/ Diagn\%C3\%B3stico-Prod-Sust-daPalma-de-\%C3\%93leo_MAPA_2018.pdf.

Monge, J. E., Chinchilla, C. M., \& Wang, A. (1993). Studies on the etiology of the crown disease / spear rot syndrome in oil palm. ASD Oil Palm Papers, 33, 1-16.

Poorter, H., \& Nagel, O. (2000). The role of biomass allocation in the growth response of plants to different levels of light, $\mathrm{CO}_{2^{\prime}}$ nutrients and water: a quantitative review. Australian Journal of Plant Physiology, 27(6), 1191. doi: 10.1071/PP97167

Pregitzer, K. S., Kubiske, M. E., Yu, C. K., \& Hendrick, R. L. (1997). Relationships among root branch order, carbon, and nitrogen in four temperate species. Oecologia, 111(3), 302-308. doi: 10.1007/ s004420050239

Rodríguez, W., \& Leihner, D. (2006). Análisis de crecimiento vegetal. Fisiología de la producción de cultivos tropicales. San José: Editorial Universidad de Costa Rica.

Shull, G. H. (1908). The composition of a field of maize. Journal of Heredity, 4(1), 296301. doi: 10.1093/jhered/os-4.1.296

Silva, P. A., Cosme, V. S., Rodrigues, K. C. B., Detmann, K. S. C., Leão, F. M., Cunha, R. L., Pinheiro, H. A. (2017). Drought tolerance in two oil palm hybrids as related to adjustments in carbon metabolism and vegetative growth. Acta Physiologiae Plantarum, 39(2), 58. doi: 10.1007/s117 38-017-2354-4

Souza, T. C. de, Magalhães, P. C., Castro, E. M. de, Duarte, V. P., \& Lavinsky, A. O. (2016). Corn root morphoanatomy at different development stages and yield under 
water stress. Pesquisa Agropecuária Brasileira, 51(4), 330-339. doi: 10.1590/ S0100-204X2016000400005

Szaniawski, R. K. (1983). Adaptation and functional balance between shoot and root activity of sunflower plants grown at different root temperatures. Annals of Botany, 51(4), 453-459. doi: 10.1093/ oxfordjournals.aob.a086490

Trindade, D. R., Poltronieri, L. S., \& Furlan, J., Jr. (2005). Abordagem sobre o estado atual das pesquisas para a identificação do agente causal do amarelecimento fatal do dendezeiro. Pragas e doenças de cultivos amazônicos. Belém, PA: Embrapa Amazônia Oriental.

Turner, P. D., \& Planters, I. S. (1981). Oil palm diseases and disorders. Kuala Lumpur: Oxford University Press. Retrieved from https://books.google.com.br/books?id=5 -7wAAAAMAAJ
United States Department of Agriculture (2019). Foreign Agricultural Service. Retrieved from https://apps. fas.usda.gov/ psdonline/app/index.html\#/app/ad

UnitedStatesDepartmentofAgriculture(2021). Palm oil explorer. Retrieved from https:// ipad.fas.usda.gov/cropexplorer/cropview/ commodityView.aspx?cropid $=4243000$

Van Slobbe, W. G. (1991). Amarelecimento fatal: final report. Belém, PA: Denpasa .

Venturieri, A., Fernandes, W. R., Boari, A. de J. A. D. J., \& Vasconcelos, M. A. (2009). Relação entre ocorrência do amarelecimento fatal do dendezeiro (Elaeis guineensis Jacq.) e variáveis ambientais no Estado do Pará. Anais do Simpósio Brasileiro de Sensoriamento Remoto, Natal, RN, Brasil, 14. 
